\title{
THE RESPONSE OF SUGARCANE IN PUERTO RICO TO VARIOUS NITROGEN SOURCES
}

\author{
George Samuels, Pablo Landrau, Jr., and Bernardo G. Capó ${ }^{1}$ \\ INTRODUCTION
}

Nitrogen is of great importance in the fertilization of agricultural crops in Puerto Rico. The response in higher yields is greater for nitrogen than for any other fertilizer element used. Extensive experimentation by the Agricultural Experiment Station of the University of Puerto Rico and actual practices of the farmers have proven the truth of these statements.

Up to and including the present, ammonium sulfate has been the chief source of fertilizer nitrogen used in Puerto Rico. By comparison, the use of sodium nitrate, urea compounds, and ammonium nitrate has been minor. This is clearly shown in table 1 where ammonium sulfate is the leading nitrogen source imported for fertilizer production, despite the decrease in the 1941-45 war period when imports were limited by restrictions in shipping space.

During World War II, attention was called to the need of data on the relative efficiency of nitrogen sources. Sharp restrictions on both production and shipping of fertilizers demanded the utmost efficiency in fertilizer materials, particularly nitrogen-bearing ones. Ammonium nitrate also appeared on the market at that time when produced in excess of war requirements, and some of this material was assigned for use as a fertilizer nitrogen carrier. The introduction of ammonium nitrate as a substitute for ammonium sulfate made it advisable to determine whether the former was as effective as the latter for sugarcane and other crops in Puerto Rico.

With these points in mind experimentation was begun by the Agronomy and Horticulture Department of the Agricultural Experiment Station to study specifically whether ammonium nitrate could be substituted for ammonium sulfate as a nitrogen fertilizer in Puerto Rico. Interest was also renewed in the comparison of the effectiveness of different nitrogen sources as fertilizer materials. Because over 70 percent $^{2}$ of the fertilizer used in Puerto Rico is applied to sugarcane, field experiments were performed with this crop to make such comparisons.

\footnotetext{
${ }_{1}$ Plant Physiologist, Assistant Agronomist, and Assistant Director for Research, respectively, Agricultural Experiment Station, University of Puerto Rico, Río Piedras, P. R. The authors wish to thank the following for their cooperation in the handling of the field experiments: A. Riollano, F. Aróstegui, P. Richardson, A. Emanuelli, F. J. Juliá, R. K. Giles, and R. Irizarry.

2 The mean for the period 1942-49 compiled from data taken from (2).
} 


\section{EARLIER WORK}

Experiments with various forms of nitrogen fertilizers in Puerto Rico have been limited. Fernández García (3) ${ }^{3}$ working with sugarcane on a Ponce loam soil at Colonia Laurel, Central Mercedita, Ponce, compared ammonium sulfate and sodium nitrate as a nitrogen source. A summary of his results is presented in table 2 . There was no significant difference in yield of cane between the ammonium sulfate and sodium nitrate treatments. Méndez and Chardón (6) conducted experiments on sugarcane over a period of 5 years to compare ammonium sulfate, sodium nitrate, and calcium cyanamide as nitrogen sources. The results are given in table 3 . There was

TABLE 1.-Nitrogen fertilizers imported into Puerto Rico during the period 1936-491

\begin{tabular}{c|c|c|c|c|c|c}
\hline & \multicolumn{6}{|c}{ Nitrogenous material in tons (2,000 pounds) of- } \\
\cline { 2 - 7 } Fiscal year & Cyanamide & $\begin{array}{c}\text { Sodium } \\
\text { nitrate }\end{array}$ & $\begin{array}{c}\text { Ammonium } \\
\text { sulfate }\end{array}$ & $\begin{array}{c}\text { Ammonium } \\
\text { nitrate }\end{array}$ & Uramon & $\begin{array}{c}\text { Ammonium } \\
\text { superphos- } \\
\text { phate }\end{array}$ \\
\cline { 2 - 7 } $1936-37$ & 1,998 & 367 & 101,520 & - & - & - \\
\cline { 2 - 7 } $1937-38$ & 1,359 & 367 & 87,879 & - & - & - \\
$1938-39$ & 1,019 & 162 & 59,318 & - & - & - \\
$1939-40$ & 2,012 & 1,635 & 82,978 & - & - & - \\
$1940-41$ & 3,720 & 435 & 81,133 & - & 3,755 & 3,133 \\
$1941-42$ & 776 & 250 & 67,299 & - & 100 & 4,094 \\
$1942-43$ & - & - & 32,839 & - & - & - \\
$1943-44$ & 100 & - & 65,826 & 25,904 & - & 9,689 \\
$1944-45$ & 105 & - & 73,494 & 21,963 & 5,200 & - \\
$1945-46$ & 1,794 & 70 & 70,769 & 16,301 & - & 2,208 \\
$1946-47$ & 3,342 & 298 & 83,899 & 30,466 & - & 11,986 \\
$1947-48$ & 2,796 & 794 & 69,480 & 19,098 & -- & 40,978 \\
$1948-49$ & 3,082 & 148 & 91,080 & 8,023 & -- & 27,886 \\
\hline
\end{tabular}

1 Data compiled from the Departamento de Agricultura y Comercio de Puerto Rico, Laboratorio Químico, Informes Anuales, 1936-37 a 1948-49.

no significant difference in yield of cane that could be attributed to any of the nitrogen sources used.

The annual reports of the Agricultural Experiment Station of Puerto Rico record two experiments with organic-nitrogen sources. The first, reported by López-Domínguez (5), compared tankage with ammonium sulfate on sugarcane from 1912 to 1917. Tankage at the rate of 600 pounds per acre was tested against ammonium sulfate at the rate of 60 pounds per acre, both treatments being made with and without lime. The yields of cane were almost the same for limed and unlimed plots, regardless of nitrogen

${ }^{3}$ Numerals in parentheses refer to Literature Cited, p. 239. 
source. The average for 4 years was 23.0 and 23.4 tons cane per acre for the limed ammonium sulfate and tankage treatments, respectively, and 20.3 and 20.1 for the unlimed, respectively. Clavell (1) reports a 9-year experiment in which Crotalaria striata was used as a green-manure crop for sugarcane. The crotalaria was plowed under when in bloom, and the sugarcane was planted 3 to 4 months later. A plant cane and ratoon were

TABLE 2.-Relative effect of ammonium sulfate and sodium nitrate sources of nitrogen on yields of sugarcane ${ }^{1}$

\begin{tabular}{|c|c|c|c|c|c|c|}
\hline \multirow{2}{*}{ Nitrogen carrier } & \multicolumn{3}{|c|}{ Treatment in pounds per acre of - } & \multicolumn{3}{|c|}{ Yield in tons of cane per acre } \\
\hline & $\mathrm{NH}_{3}$ & $\mathrm{P}_{2} \mathrm{O}_{5}$ & $\mathrm{~K}_{2} \mathrm{O}$ & $\begin{array}{l}\text { Plant } \\
\text { cane }\end{array}$ & $\begin{array}{c}\text { First } \\
\text { ratooon }\end{array}$ & $\begin{array}{l}\text { Mean of } \\
\text { two crops }\end{array}$ \\
\hline Ammonium sulfate. . & 90 & 60 & 60 & 33.3 & 24.4 & 28.7 \\
\hline Sodium nitrate..... & 90 & 60 & 60 & 31.7 & 26.0 & 28.8 \\
\hline Ammonium sulfate. & 120 & 60 & 60 & 33.2 & 26.8 & 30.0 \\
\hline Sodium nitrate.... & 120 & 60 & 60 & 32.2 & 26.6 & 29.4 \\
\hline Ammonium sulfate....... & 150 & 60 & 60 & 32.3 & 25.2 & 29.3 \\
\hline Sodium nitrate.......... & 150 & 60 & 60 & 32.4 & 27.0 & 29.7 \\
\hline Ammonium sulfate........ & 180 & 60 & 60 & 37.2 & 28.4 & 32.8 \\
\hline Sodium nitrate........ & 180 & 60 & 60 & 34.5 & 27.8 & 31.1 \\
\hline Check.............. & 0 & 60 & 60 & 27.8 & 19.6 & 23.8 \\
\hline \multirow{2}{*}{\multicolumn{4}{|c|}{$\begin{array}{l}\text { Least significant difference at: } \\
5 \text { percent } \ldots \ldots \ldots \ldots \ldots \ldots\end{array}$}} & & & \\
\hline & & & & 7.4 & 9.5 & 6.4 \\
\hline \multicolumn{4}{|l|}{1 percent... } & 9.9 & 12.8 & 8.7 \\
\hline
\end{tabular}

${ }^{1}$ Compiled from the field data of the experiment of Fernández-García a summary of which is given in (3).

TABLE 3.-Effect of different nitrogen carriers on yields of sugarcane ${ }^{1}$

\begin{tabular}{|c|c|c|c|c|c|c|}
\hline \multirow{2}{*}{ Nitrogen carrier } & \multicolumn{6}{|c|}{ Yield of cane in tons per acre in- } \\
\hline & 1936 & 1937 & 1938 & 1939 & 1940 & $\begin{array}{c}5 \text {-year } \\
\text { average }\end{array}$ \\
\hline Calcium cyanamide. & 60.1 & 35.4 & 33.5 & 32.8 & 27.1 & 37.8 \\
\hline Ammonium sulfate. & 62.1 & 36.0 & 33.3 & 31.1 & 27.8 & 38.1 \\
\hline Sodium nitrate.... & 64.3 & 34.7 & 32.2 & 32.3 & 28.0 & 38.3 \\
\hline
\end{tabular}

${ }^{1}$ Compiled from field data of an experiment by Méndez and Chardón (6).

grown before the next planting of crotalaria. No significant difference in yield took place as compared with cane on which the customary inorganic fertilizer was used in which ammonium sulfate was the nitrogen source.

\section{Recent Experiments}

Recent sugarcane experiments have been conducted on a Fraternidad clay at Santa Rita, Guánica; a Coto clay at Isabela Substation; and a 
Vega Alta clay loam at Río Piedras. The results of these experiments will be taken up individually.

The experiment performed at Santa Rita, Guánica, is summarized in table 4 . There was no significant difference between the nitrogen sources used, whether in one application or two. As a check treatment in which no nitrogen was applied was not included in this experiment, possibly the lack of differential response to the different nitrogen sources is attributable to the fact that the soil contained sufficient nitrogen for the production of maximum yield.

The Isabela Substation experiment with sugarcane consisted in comparing ammonium sulfate and ammonium nitrate as nitrogen sources. The plant cane showed no significant differences in yield that could be attributed to the nitrogen source used (see table 5). The yields under the

TABLE 4.-Ammonium nitrate versus ammonium sulfate as a nitrogen source for sugarcane, Santa Rita, Guánica, 1944-45

\begin{tabular}{|c|c|}
\hline Treatment & $\begin{array}{l}\text { Mean yield of } 15 \text { replicates in } \\
\text { hundredweights of } \\
\text { sugar per acre }\end{array}$ \\
\hline $\begin{array}{l}\text { Ammonium nitrate applied once at the rate of } 200 \text { pounds } \\
\mathrm{NH}_{3} \text { per acre } \ldots \ldots \ldots \ldots \ldots \ldots \ldots \ldots \ldots \ldots \ldots \ldots \ldots \ldots \ldots \ldots \ldots \ldots\end{array}$ & 91.8 \\
\hline Ammonium sulfate at the same rate $\ldots \ldots \ldots \ldots \ldots \ldots$ & 100.1 \\
\hline Ammonium nitrate applied twice at rate of 100 pounds & \\
\hline $\mathrm{NH}_{3}$ per acre per application............... & 97.7 \\
\hline Ammonium sulfate at the same rate $\ldots \ldots \ldots \ldots \ldots \ldots$ & 94.8 \\
\hline Least significant difference between two means at: & 10.4 \\
\hline 1 percent. $\ldots \ldots \ldots \ldots \ldots \ldots \ldots \ldots \ldots \ldots \ldots \ldots \ldots$ & 13.9 \\
\hline
\end{tabular}

ammonium sulfate treatment were significantly higher than those when no nitrogen was used. The omission of ammonium sulfate reduced yields 14 percent, of ammonium nitrate, 7 percent. There was no response to phosphorus or potassium when nitrogen was omitted.

In the first ratoon crop of this experiment, ammonium sulfate gave yields higher than ammonium nitrate, which were significant at the 1-percent point. Both nitrogen sources gave yields significantly higher than the nonitrogen treatment. The reduction in yield from the omission of ammonium sulfate was 34 percent, from the omission of ammonium nitrate, 20 percent.

In the first sugarcane experiment at Río Piedras ammonium sulfate, ammonium nitrate in one and two applications, and Uramon were compared. The experiment comprised a plant cane and two ratoons. The results in terms of yields of available $96^{\circ}$ sugar are summarized in table 6 . In all 3 crops there was a significant difference in yield between the no-nitrogen 
and the nitrogen treatments. There was no significant difference in yield whether ammonium nitrate was used in one or two applications. This was

TABLE 5.-A comparison of ammonium sulfate and ammonium nitrate as sources of nitrogen for sugarcane, Isabela Substation, 1944-46

\begin{tabular}{|c|c|c|c|c|c|}
\hline \multirow{2}{*}{ Nitrogen carrier } & \multicolumn{3}{|c|}{ Treatment in pounds per acre of -} & \multicolumn{2}{|c|}{$\begin{array}{c}\text { Mean yield of } 18 \text { replications } \\
\text { in hundredweights of } \\
\text { sugar per acre }\end{array}$} \\
\hline & $\mathrm{NH}_{3}$ & $\mathrm{P}_{2} \mathrm{O}_{5}$ & $\mathrm{~K}_{2} \mathrm{O}$ & $\begin{array}{c}\text { Plant cane } \\
1944-45\end{array}$ & $\begin{array}{c}\text { First ratoon } \\
1945-46\end{array}$ \\
\hline None. & 0 & 0 & 0 & 89.4 & - \\
\hline Do.. & 0 & 72 & 120 & 88.0 & 54.0 \\
\hline Ammonium sulfate...... & 168 & 72 & 120 & 102.7 & 78.5 \\
\hline Ammonium nitrate...... & 168 & 72 & 120 & 94.7 & 67.3 \\
\hline Ammonium sulfate...... & 168 & 0 & 0 & - & 68.7 \\
\hline \multicolumn{4}{|c|}{$\begin{array}{r}\text { Least significant difference between any two means at: } \\
5 \text { percent. } \\
1 \text { percent. }\end{array}$} & $\begin{array}{l}10.2 \\
13.6\end{array}$ & $\begin{array}{r}8.6 \\
11.5\end{array}$ \\
\hline
\end{tabular}

TABLE 6.-A comparison of the efficiency of different nitrogen sources on available $96^{\circ}$ sugar at Rio Piedras

[Yields of available $96^{\circ}$ sugar]

\begin{tabular}{|c|c|c|c|c|c|c|c|}
\hline \multirow{2}{*}{ Nitrogen carrier } & \multicolumn{3}{|c|}{$\begin{array}{l}\text { Treatment in pounds } \\
\text { per acre of- }\end{array}$} & \multicolumn{4}{|c|}{$\begin{array}{l}\text { Mean yield of } 16 \text { replications in } \\
\text { hundredweights of available } \\
96^{\circ} \text { sugar per acre }\end{array}$} \\
\hline & $\mathrm{NH}_{3}$ & $\mathrm{P}_{2} \mathrm{O}_{5}$ & $\mathrm{~K}_{2} \mathrm{O}$ & $\begin{array}{c}\text { Plant } \\
\text { cane, } \\
1944-45\end{array}$ & $\begin{array}{c}\text { First } \\
\text { ratoon, } \\
1945-46\end{array}$ & $\begin{array}{l}\text { Second } \\
\text { ratoon, } \\
1946-47\end{array}$ & $\mid \begin{array}{c}\text { Mean } \\
\text { yield of } \\
3 \text { crops }\end{array}$ \\
\hline None. & 0 & 50 & 50 & 58 & 66 & 100 & 75 \\
\hline Ammonium sulfate........ & 250 & 50 & 50 & 86 & 86 & 132 & 101 \\
\hline $\begin{array}{l}\text { Ammonium nitrate, one applica- } \\
\text { tion } \ldots \ldots \ldots \ldots \ldots \ldots \ldots \ldots \ldots \ldots\end{array}$ & 250 & 50 & 50 & 88 & 83 & 126 & 99 \\
\hline 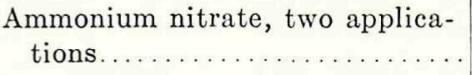 & 250 & 50 & 50 & 79 & 84 & 123 & 96 \\
\hline Uramon.................. & 250 & 50 & 50 & 87 & 83 & 122 & 97 \\
\hline \multicolumn{4}{|l|}{$\begin{array}{l}\text { Least significant difference at: } \\
5 \text { percent................ }\end{array}$} & 7.0 & 7.0 & 9.9 & 6.2 \\
\hline \multicolumn{4}{|l|}{1 percent. } & 9.3 & 9.4 & 13.1 & 8.2 \\
\hline
\end{tabular}

also true of ammonium sulfate in the experiment performed at Guánica (see table 4).

The available $96^{\circ}$ sugar as percent cane was not significantly different regardless of the treatment used (see table 7), though lack of nitrogen lowered yields in the plant cane. This difference was significant only at 
the 5 -percent point. The results in table 7 indicate clearly that, for this experiment, the nitrogen source used did not adversely affect the sucrose content of the cane. Failure of high-nitrogen treatments to lower the sucrose content of cane has occurred before in other experiments performed at the Station. The often-stated belief that high-nitrogen treatments stimulate vegetative growth too much, and decrease the sucrose content of the cane seems to be groundless in most cases.

A second experiment was made at Río Piedras on a Vega Alta clay loam comparing ammonium sulfate, ammonium nitrate, liquid ammonium nitrate, and cyanamide. The schedule of treatments and yields of the plant cane are given in table 8 . All nitrogen sources used, except liquid ammonim

TABLE 7.-A comparison of the efficiency of different nitrogen sources on available $96^{\circ}$ sugar percent cane at Rio Piedras

[Available $96^{\circ}$ sugar as percent cane]

\begin{tabular}{|c|c|c|c|c|c|c|}
\hline \multirow{2}{*}{ Nitrogen carrier } & \multicolumn{3}{|c|}{ Treatment in pounds per acre of- } & \multicolumn{3}{|c|}{$\begin{array}{l}\text { Mean yield of } 16 \text { replications in } \\
96^{\circ} \text { sugar percent cane }\end{array}$} \\
\hline & $\mathrm{NH}_{3}$ & $\mathrm{P}_{2} \mathrm{O}_{5}$ & $\mathrm{~K}_{2} \mathrm{O}$ & $\begin{array}{l}\text { Plant } \\
\text { cane, } \\
1944-45\end{array}$ & $\begin{array}{l}\text { First } \\
\text { ratoon, } \\
1945-46\end{array}$ & $\begin{array}{l}\text { Second } \\
\text { ratoon, } \\
1946-47\end{array}$ \\
\hline None.. & 0 & 50 & 50 & 11.61 & 12.43 & 12.32 \\
\hline Ammonium sulfate....... & 250 & 50 & 50 & 12.46 & 12.15 & 11.78 \\
\hline $\begin{array}{l}\text { Ammonium nitrate, one } \\
\text { application ............ }\end{array}$ & 250 & 50 & 50 & 12.49 & 11.91 & 11.96 \\
\hline $\begin{array}{l}\text { Ammonium nitrate, two } \\
\text { applications ............ }\end{array}$ & 250 & 50 & 50 & 12.09 & 12.06 & 12.05 \\
\hline Uramon....... & 250 & 50 & 50 & 12.26 & 12.42 & 12.30 \\
\hline \multicolumn{4}{|c|}{$\begin{array}{l}\text { Least significant difference between means at: } \\
5 \text { percent } \ldots \ldots \ldots \ldots \ldots \ldots \ldots \ldots \ldots \ldots \ldots \ldots \ldots \ldots \ldots\end{array}$} & $\begin{array}{r}0.60 \\
.80\end{array}$ & $\begin{array}{r}0.54 \\
.72\end{array}$ & $\begin{array}{r}0.56 \\
.74\end{array}$ \\
\hline
\end{tabular}

nitrate produced yields significantly higher than when no nitrogen was used, when all the fertilizers were applied in the liquid form, the yield was only 3 hundredweights higher than when no nitrogen was used. The reason for this may have been rapid leaching of the liquid source before adequate use can be made of it by the plant. Previous experiments on sweet-potatoes using liquid-nitrogen sources also produced low yields (4).

Once again there was no significant difference in yield whether ammonium sulfate or ammonium nitrate was the nitrogen source. This result confirmed the findings in the first experiment at Río Piedras. Cyanamide did not produce significantly greater yields than ammonium sulfate or ammonium nitrate. 


\section{The Agro-economic Aspect of the Various Nitrogen Sources}

The substitution of ammonium sulfate for ammonium nitrate during the war period brought with it claims by the sugarcane farmers that: 1, The sugarcane crop does not respond as efficiently to the ammonium nitrate applications as it customarily does to those of ammonium sulfate; 2 , the high solubility of ammonium nitrate may cause leaching losses of nitrates, and therefore, the supply of nitrogen will be reduced during the long growth period of sugarcane. The results of the experiments to date have shown these claims to be largely unjustifiable.

The results of the Río Piedras experiments performed on a Vega Alta sandy clay in the humid section of the Island indicate that ammonium

TABLE 8.-A further comparison of different sources of nitrogen on sugarcane, plant cane, Rio Piedras, 1949-50

\begin{tabular}{|c|c|c|c|}
\hline \multirow{2}{*}{$\begin{array}{l}\text { Treatment } \\
\text { No. }\end{array}$} & \multicolumn{2}{|r|}{ Treatment } & \multirow{2}{*}{$\begin{array}{l}\text { Mean yield in } \\
\text { available } 96^{\circ} \\
\text { sugar in hun- } \\
\text { dredweights } \\
\text { per acre }\end{array}$} \\
\hline & Analysis & Pounds per acre & \\
\hline 1 & $0-6-5$ & 1,200 pounds & 75 \\
\hline 2 & $14-6-5$ & $\begin{array}{l}1,200 \text { pounds }+48 \text { pounds } \mathrm{NH}_{3} \text { as ammo- } \\
\text { nium sulfate }\end{array}$ & 104 \\
\hline 3 & $14-6-5$ & $\begin{array}{l}1,200 \text { pounds in liquid form }+48 \text { pounds } \\
\mathrm{NH}_{3} \text { as liquid ammonium nitrate }\end{array}$ & 78 \\
\hline 4 & $18-6-5$ & $\begin{array}{l}1,200 \text { pounds with } \mathrm{NH}_{3} \text { as ammonium } \\
\text { sulfate }\end{array}$ & 99 \\
\hline 5 & $18-6-5$ & $\begin{array}{l}\text { 1,200 pounds with } \mathrm{NH}_{3} \text { as ammonium ni- } \\
\text { trate }\end{array}$ & 94 \\
\hline 6 & $18-6-5$ & Cyanamide & 92 \\
\hline \multicolumn{3}{|c|}{$\begin{array}{l}\text { Least } \text { significant difference between any two means at: } \\
\quad 5 \text { percent. } \ldots \ldots \ldots \ldots \ldots \ldots \ldots \ldots\end{array}$} & $\begin{array}{l}12.7 \\
17.0\end{array}$ \\
\hline
\end{tabular}

sulfate and ammonium nitrate are equally good nitrogen sources. The Isabela experiment on a Coto clay in the irrigated northwestern part of the Island revealed a tendency for ammonium sulfate to produce higher yields than the nitrate. This was in the first ratoon and was significant at the 5-percent level. The Guánica experiment revealed no differences attributable to the nitrogen source used. The earlier work showed no differences when ammonium sulfate, sodium nitrate, and cyanamide were compared as nitrogen sources. In general, the nitrogen source used on cane for short periods like the ones used in these tests has no decided effect on yields.

In the selecting of a nitrogen source to be used as a fertilizer material in 
Puerto Rico, the following criteria should be considered: a, Nitrogen content; b, form of the nitrogen, whether $\mathrm{NH}_{3}, \mathrm{NO}_{3}$, or organic; c, cargo space equivalent per unit of nitrogen; $d$, solubility; e, physical condition for handling, hygroscopicity, plasticity, caking properties; f, residual influence on soil $\mathrm{pH}$; g, cost per unit of nitrogen.

An evaluation was made of the physical and chemical characteristics of the leading nitrogen sources used in Puerto Rico; the results are summarized in table 9 . No important differences were revealed in their value as nitrogen fertilizers. This has been shown to be true to date in most of the experiments conducted. Therefore, the choice of a nitrogen source rests mainly upon the economic factors of availability to the purchaser, cost of the material and transportation costs.

The factor of cargo-space equivalent per unit of nitrogen should be evaluated carefully in choosing a nitrogenous fertilizer. Greater quantities

TABLE 9.-Physical and chemical characteristics of materials used as sources of nitrogen

\begin{tabular}{|c|c|c|c|c|c|c|c|}
\hline Material & $\begin{array}{c}\mathrm{NH}_{3} \\
\text { content } \\
\text { (percent) }\end{array}$ & $\begin{array}{l}\text { Nitrogen } \\
\text { form }\end{array}$ & $\begin{array}{l}\text { Cargo } \\
\text { space } \\
\text { equiva- } \\
\text { lent per } \\
\text { unit of } \\
\mathrm{NH}_{3}\end{array}$ & $\begin{array}{l}\text { Solu- } \\
\text { bility } \\
\mathrm{gm} . / 100 \\
\mathrm{gm} . \mathrm{H}_{2} \mathrm{O} \\
\text { at } 70^{\circ} \mathrm{F} \text {. }\end{array}$ & $\begin{array}{l}\text { Physical } \\
\text { condition } \\
\text { for } \\
\text { handling }\end{array}$ & $\begin{array}{c}\text { Relative } \\
\text { value as } \\
\text { nitrogen } \\
\text { source for } \\
\text { sugar- } \\
\text { cane }\end{array}$ & $\begin{array}{l}\text { Residual } \\
\text { influence } \\
\text { on soil }\end{array}$ \\
\hline Ammonium sulfate. & 25 & $\mathrm{NH}_{3}$ & 4.0 & 75.4 & Good & 100.0 & Acid \\
\hline Ammonium nitrate. . & $40-42$ & $\mathrm{NH}_{3}, \mathrm{NO}_{3}$ & $2.3-2.5$ & 187.4 & Fair & 91.2 & Do. \\
\hline Cyanamide... & 22 & $\mathrm{CN}_{2}$ & 4.6 & 1 & Good & 96.0 & Alkaline \\
\hline Uramon... & 51 & $\mathrm{CO}\left(\mathrm{NH}_{2}\right)_{2}$ & 2.0 & 103.3 & do. & 95.5 & Acid \\
\hline Sodium nitrate.. & 19 & $\mathrm{NO}_{3}$ & 5.4 & 87.6 & do. & 97.8 & Alkaline \\
\hline
\end{tabular}

1 Very soluble.

of a nitrogen source with a high cargo-space equivalent must be transported to supply a unit of nitrogen than of one with a low cargo-space equivalent. As all nitrogen sources used in Puerto Rico are imported by ship, the cargospace equivalent becomes important. Ammonium sulfate, the leading nitrogen source used in the Island, has a cargo-space equivalent of 4 , which means that 4 pounds of ammonium sulfate must be shipped to supply 1 pound of nitrogen as $\mathrm{NH}_{3}$. Ammonium nitrate has an equivalent of 2.4 , meaning that only 2.4 pounds are needed to supply 1 pound of nitrogen. Uramon, a urea nitrogen source, has an equivalent of 2, thus 1 pound of it will supply as much nitrogen as 2 pounds of ammonium sulfate.

In choosing a nitrogen source one must consider the physical condition of the nitrogenous material as related to shipping, storage, handling, and incorporation into fertilizer mixtures. Ammonium nitrate which is high in nitrogen and low in cargo-space equivalent offers a good example. Although 
its difficult physical handling qualities caused by high hydroscopicity have been improved, its explosiveness when handled in bulk has limited its use in Puerto Rico. The great Texas City disaster and other explosions caused by handling of ammonium nitrate in shipping caused the U. S. Government to impose severe restrictions on its transportation in bulk. The law demands special safety precautions in shipment by boat; and because of the added expense involved, the price of ammonium nitrate in Puerto Rico is now greater than that of ammonium sulfate.

The residual influence of the nitrogen source used on soil $\mathrm{pH}$ is not a deciding factor in the choice of nitrogen sources, but it should be given some consideration. Ammonium sulfate, the main nitrogenous material used in the Island, increases the hydrogen-ion concentration of the soil solution when added to the soil. This lowering of the $\mathrm{pH}$ can prove beneficial in the southwest parts of the Island where the soil $\mathrm{pH}$ is normally above 7 . However, in the humid sections, on soils which are already acid, this lowering of the $\mathrm{pH}$ by continual use of ammonium sulfate may prove harmful. Lime should be added when fertilizing soils of low $\mathrm{pH}$ with ammonium sulfate. The use of cyanamide with its alkaline reaction would prove of value in very acid soils. Calcium cyanamide supplies the soil with 1 pound of calcium carbonate for every pound of cyanamide used. The choice of the proper nitrogen source to be used, as affected by its residual effect, is one which must be made in the light of existing soil $\mathrm{pH}$, the soil type, the crop, and the quantity of nitrogenous material to be used.

The status of the nitrogen sources used in Puerto Rico should not be regarded as static. The question must be weighed in the light of new agricultural chemical discoveries and further field experimentation. Fortunately, the Agricultural Experiment Station has adopted a research program which constantly tests both new and promising as well as existing nitrogen sources in the varied soil and climatic conditions of Puerto Rico.

\section{Summary}

1. A survey of the literature of earlier fertilizer trials in Puerto Rico in which the efficiency of ammonium sulfate, sodium nitrate, tankage, and calcium cyanamide were compared revealed that there was no significant difference in the yield response of sugarcane to these nitrogen carriers.

2. Experiments were conducted in which ammonium sulfate and ammonium nitrate were compared as nitrogen sources for sugarcane. The results at Río Piedras and Guánica showed no significant differences in yield of cane or sugar regardless of which was used. At Isabela there was a better response to ammonium sulfate than to ammonium nitrate in the first ratoon, but it was significant only at the 5 -percent point.

3. Uramon and cyanamide when tested along with the ammonium sulfate 
and nitrate experiments at Río Piedras and Isabela, produced no significant responses as compared with the other nitrogen sources. At Río Piedras liquid ammonium nitrate produced the lowest yield of any nitrogen source used.

4. Ammonium sulfate is the chief nitrogen source used in Puerto Rico. Its use is chiefly dictated by economic and manufacturing conditions. Ammonium nitrate, which is cheaper per unit of nitrogen, cannot be used at present because of extremely high transportation costs based on its explosiveness.

5. A discussion of the agro-economic aspect of nitrogen sources is presented.

\section{Literature Cited}

1. Clavell, C. J., Annual Report of Insular Experiment Station, Puerto Rico, p. 29, 1939-1940.

2. Laboratorio Químico, Departamento de Agricultura y Comercio de Puerto Rico, Informe Anual, años 1936-37 a 1948-49.

3. Fernández-García, R., Annual Report of Insular Experiment Station, Puerto Rico, p. 84-85, 1927-28.

4. Landrau, P. and Samuels, G., Annual Report of Agronomy Department, Agricultural Experiment Station, University of Puerto Rico, (unpublished) 1949-50.

5. López-Domínguez, F. A., Fertilizer Experiments on Sugar Cane, Insular Experiment Station, Bulletin No. 29, 1923.

6. Méndez, F. and Chardón, F., Annual Report of Agricultural Experiment Station, Puerto Rico, p. 27-28, 1939-1940. 